IZA DP No. 9050

Obesity and Economic Performance of Young Workers in Italy

Giovanni S. F. Bruno

Floro E. Caroleo

Orietta Dessy

May 2015 


\title{
Obesity and Economic Performance of Young Workers in Italy
}

\author{
Giovanni S. F. Bruno \\ Bocconi University, Milan \\ Floro E. Caroleo \\ University of Naples "Parthenope", \\ CRISEI and IZA \\ Orietta Dessy \\ Cà Foscari University, Venice \\ and Catholic University, Milan
}

Discussion Paper No. 9050

May 2015

IZA

\author{
P.O. Box 7240 \\ 53072 Bonn \\ Germany
}

Phone: +49-228-3894-0
Fax: +49-228-3894-180
E-mail: iza@iza.org

Any opinions expressed here are those of the author(s) and not those of IZA. Research published in this series may include views on policy, but the institute itself takes no institutional policy positions. The IZA research network is committed to the IZA Guiding Principles of Research Integrity.

The Institute for the Study of Labor (IZA) in Bonn is a local and virtual international research center and a place of communication between science, politics and business. IZA is an independent nonprofit organization supported by Deutsche Post Foundation. The center is associated with the University of Bonn and offers a stimulating research environment through its international network, workshops and conferences, data service, project support, research visits and doctoral program. IZA engages in (i) original and internationally competitive research in all fields of labor economics, (ii) development of policy concepts, and (iii) dissemination of research results and concepts to the interested public.

IZA Discussion Papers often represent preliminary work and are circulated to encourage discussion. Citation of such a paper should account for its provisional character. A revised version may be available directly from the author. 
IZA Discussion Paper No. 9050

May 2015

\section{ABSTRACT}

\section{Obesity and Economic Performance of Young Workers in Italy}

In this paper we explore recent ISFOL-PLUS 2006-2008-2010 data available for Italy about height and weight of young workers with the purpose of analysing the relationship between measures of obesity and measures of economic performance. Among the latter, we introduce job satisfaction, both overall and for nine specific aspects, which has not been previously considered in the literature on the effects of obesity. Interestingly enough, we find that BMI does not discriminate young workers with respect to their job earnings, but it does affect negatively young workers' job satisfaction with important gender effects.

JEL Classification: J28, J81, I14

Keywords: obesity, overweight, body mass index, job satisfaction, gross income

Corresponding author:

Floro Ernesto Caroleo

Department of Business and Economics Studies

University of Naples "Parthenope"

Via Generale Parisi n. 13

I-80133 Napoli

Italy

E-mail: caroleo@uniparthenope.it 


\section{Introduction}

It is a well-known fact that obesity is nowadays one of the most important public health concerns: obesity is a risk factor for numerous health problems and many chronic diseases and its prevalence has increased by 10-40\% in most European countries over the last decade (WHO (2003)). Moreover, obesity affects not only adults but also teenagers and children, especially in southern Europe (IOTF (2002),IOTF (2003)).

For all these reasons, it is important to assess both the determinants and the consequences of obesity. The effects of obesity on labor market outcomes for the US have been established in a large number of studies. One of the most robust findings is that obese women tend to earn less than their non-obese counterparts and that there are differences by ethnicity and/or race (Cawley (2000), Cawley (2004)). Wage and occupational effects for men are less dramatic. The evidence available for Europe is overall consistent with what found for the US, although the differences found among countries can be explained either with cultural aspects or with the methodologies applied. One fundamental issue in this literature is in fact the endogeneity of obesity. Obesity might lower wages by lowering productivity or because of workplace discrimination. But at the same time low wages might cause obesity because poorer people consume cheaper, more fattening foods. Moreover, unobserved variables might cause both obesity and low wages. This problem has been dealt with in many different ways in the literature, according to the information available and the estimation method applied.

In this chapter we present recent evidence for Italy, a country for which to our knowledge no previous analyses on obesity are available. The originality of our approach consists in taking into account not only the usual quantitative measures for evaluating the labor market outcome of people overweight (wages and probability of having a job), but also a number of qualitative aspects of the job that previously have not been considered.

Our effort is to open the analysis of the consequences of obesity on the labor market to a recent multidimensional perspective adopted by a number of international institutions (the United Nations Millennium Declaration, approved by the UN Assembly in September 2000; ILO, in its school to work transition survey, as explained in Elder (2009); Lisbon Agenda, 2000; Eurofound (2007) and Eurofound (2012)) for evaluating jobs. Indeed, undertakings have been made not only to increase employment, but also to improve its quality. The question therefore arises as to whether obese workers can be

discriminated against not only in terms of probability of being hired or in terms of wages but also for the quality of their jobs.

In this paper we attempt to answer this question, focussing on the quality of jobs among young workers as reflected by their own perceived job satisfaction levels. In fact, although workers' job satisfaction has been widely analysed by sociologists and industrial psychologists, it also conveys useful information about economic life and labour market decisions that should not be ignored (Freeman (1978); Eurofound (2007)). 
Job satisfaction is a subjective measure of how people feel about their job. Broadly speaking, it can be thought of as a multidimensional construct involving subjective aspirations and objective opportunities. In this paper we focus on so-called cognitive job satisfaction, which is the extent of the individual's satisfaction with particular aspects of their jobs, such as the work environment, work organization, duties, protection against sickness, accident and industrial injury, career perspectives, pay, competence and skills development, and job security.

Not only is job satisfaction useful as a proxy for job quality, but also for the following two reasons. First, it increases job productivity (Hamermesh (1997)) and therefore firm productivity (Oswald (1997)); and second it improves social welfare, as it is extremely closely correlated to overall individual happiness and well-being (social life, family, etc.) (Addabbo and Solinas (2012)). ${ }^{1}$

For our analysis we use the 2006-2008-2010 panel collected by the Institute for Workers' Professional Development (Istituto per lo Sviluppo della Formazione Professionale dei Lavoratori, ISFOL) in the Participation, Labour, Unemployment Survey (PLUS). This data set has a number of advantages for the purposes of our research: 1) it is a panel, and as such it allows us to treat unobserved heterogeneity across workers, which is crucial when working with models of personal evaluation; 2) it covers a time period that is subsequent to the introduction of labour market reforms meant to improve the labor market performance of young workers in Italy; 3) it includes self-declared measures of height and weight, that allow the construction of the Body Mass Index (BMI) to classify individuals as obese or not, as in most of the previous literature; 5) it presents a unique wealth of information about selfdeclared satisfactions on an uncommonly large number of job-aspect satisfactions. More specifically, we observe nine dimensions of job satisfaction, whereas for other countries' data far fewer levels are available (for example four in Green and Heywood (2011); five in de Graaf-Zijl (2012)). As a classical measure of labor market outcome we also consider wages.

Endogeneity of obesity could be an issue also in a job-satisfaction model, although the reason why this may be so is less obvious than in a wage equation. It may be for example that latent individual traits affect the eating habits of an individual along her/his well-being in the work-place. There could be also an inverse causality effect if bad conditions of work and low job satisfaction may bring about a change in the diet for an individual. A this stage of the analysis, we do not pursue the endogeneity issue beyond an attempt to control for correlated latent heterogeneity.

Our findings are the following. We find that for young people in Italy the wage-penalty of obesity is never existent. Conversely a job-satisfaction effect of obesity clearly emerges and the aspects of job satisfaction for which obese men and women are dissatisfied are different.

The chapter is organised as follows: in Section 2 we revise the existing literature on the consequences in the labor market of obesity, mainly in the European countries. Section 3 describes our data. Section 4 presents the econometric analysis and Section 5 concludes. Tables are relegated into an appendix.

\footnotetext{
${ }^{1}$ For other analyses of job satisfaction, in particular related to contractual characteristics of workers, see for example van Praag et al., 2003, for Germany; de Graaf-Zijl (2012) for the Netherlands; A. Booth and Frank (2002), Bardasi and Francesconi (2004) and Green and Heywood (2011)for the UK; Bruno et al. 2013 for Italy.
} 


\section{The literature}

The analysis of the economic consequences of obesity in the labor market has quite a long story. Obesity is one way of measuring and taking into account the physical attractiveness of individuals considered for the first time in economics by Biddle and Hamermesh (1994), Biddle and Hamermesh (1998). Since then, the empirical research has followed two different strands: one is to construct subjective measures of beauty, a concept that is difficult to quantify since it is exquisitely subjective; the other is to work with more objective measures of beauty, based on the observation of height, weight, fat mass, BMI, or other quantifiable aspects of perceived physical attractiveness ${ }^{2}$.

In this chapter we follow the second strand of the literature, therefore in this section we will briefly survey the economic literature on obesity, focussing on the European case.

The evidence about the economic consequences of obesity in the European countries covers mainly the last decennium and a limited number of countries: UK (Sargent and Blanchflower (1994), Morris (2006)); Germany (J. Cawley and Lillard (2005)); Finland ( Sarlio-Lahteenkorva and Lahelma (1999)); Denmark (Greve (2005)) and Germany (Caliendo and Gehrsitz (2014)). In the work by Sargent and Blanchflower (1994), hourly earnings of women at age 23 are found to be lower conditioned on being obese at age 16, but no such a relation is found for men. More recently, Morris (2005), Morris (2006) shows that body mass index (BMI) has a positive and significant effect on mean hourly occupational earning in males and a negative and significant effect in females, although the association for males is not robust across different specifications. However, after using the mean BMI (and/or the prevalence of obesity) across individuals living in the same health authority area as an instrument for individual BMI, he finds no statistically significant effect, either for men or for women. In Finland, obese females are found to have lower income levels than non-obese ones, but that is not the case for males (Sarlio-Lahteenkorva and Lahelma (1999)). The empirical evidence for Germany shows that obesity is negatively associated with wages, both for men and for women (J. Cawley and Lillard (2005)). Finally, preliminary evidence for Denmark shows a negative effect of obesity and overweight on employment for women, while for men overweight seems to have a positive effect on employment (Greve (2005)).

On the other hand, there are some comparative studies across the European countries carried out on the 1998-2001 waves of European Community Household Panel (ECHP) that find contrasting results according to the methodology of the analysis carried out. Villar and Quintana-Domeque (2006), Brunello and d'Hombres (2007) and V. Atella and Vuri (2008) analyze the effect of BMI on wages in Europe. With their descriptive evidence, Villar and Quintana-Domeque (2006), find overall no wage or gender effects in Europe, however the heterogeneous correlations found across countries can be explained with cultural or institutional settings (collective bargaining coverage, provision of health insurance by employer, prevalence of obesity in the country, and social interactions). Brunello and

\footnotetext{
${ }^{2}$ For a recent analysis of the relationship between subjective and anthropometric measures of attractiveness see Oreffice and Quintana-Domenque (2014)
} 
d'Hombres (2007) instead, pooling all the countries together, find that the association between BMI and wages is negative for women, and positive for men. Using BMI from biological family members as an instrument for individual BMI, they report a negative effect of BMI for both men and women and therefore no gender effect. Interestingly enough, Brunello and d'Hombres (2007) highlight a geographical effect: obese workers pay a wage penalty in 'olive belt' countries (Spain, Greece, Italy, Portugal) and earn a positive premium in 'beer belt' countries (Austria, Ireland, Denmark, Belgium, Finland). Controls for country-GDP per capita and temperature seem to explain this evidence as follows: in worm countries obese people are less productive than in cold countries and this explains their lower wages. On the same data V. Atella and Vuri (2008) apply an original method: quantile regression with instrumental variables. They also find high heterogeneity in Europe as the relationship between obesity and wages changes across countries and wage quantiles, but in their case cultural, environmental or institutional settings do not seem to be able to explain differences across countries. According to V. Atella and Vuri (2008) the observed differences across countries are therefore due to a pure discriminatory effect hypothesis.

Sousa (2005) and Villar and Quintana-Domeque (2006) focus on the probability to be employed for obese people. Sousa (2005) applies the propensity score technique (matching estimator) in order to assess the causal effect of BMI on the successful outcome in the labor market. Pooling all the countries together, she finds that the average treatment effect for those having a BMI above 25 decreases labor force participation for women, whereas it increases male labor force participation. Villar and QuintanaDomeque (2006) instead find no employment or segregation effects with their descriptive analysis.

Finally, there is a recent study by P. Lundborg and Lindgren (2007) carried out on the 2004 wave of the Survey of Health, Aging and Retirement in Europe (SHARE) where the authors analyze the effect of obesity on employment, hours worked and hourly wages in 10 European countries for people aged 50

and above. Pooling all the countries together and using as instrumental variables birth order and the sibling sex composition of the respondent, they find that obesity is negatively associated with being employed for both men and women and with female hourly wages. They also observe heterogeneity across EU-countries: the effects of obesity on employment are bigger for men in Southern or Central Europe whereas the effects on wages are worse for women in Central Europe.

The purpose of our paper is to study this issue for Italy, focusing on young people. To our knowledge no previous studies for this country have been carried out.

\section{The data}

Our empirical analysis is based on micro-data collected by ISFOL in the Participation, Labour, Unemployment Survey (PLUS). This survey, started in 2005, consists in a sample of about 38,000 workingage people interviewed by telephone. Detailed personal data, information about education, family 
background, occupational characteristics and job search condition are collected ${ }^{3}$.

In methodological terms, the representativeness of the sample follows exactly the same criteria as the national survey carried out by the Italian National Institute of Statistics (ISTAT): the Labour Force Survey (LFS). But the general purpose of the PLUS questionnaire is also to record people's self-perceptions about different aspects of their lives, and especially of their jobs, thereby completing the canonical information available in the LFS. In our analysis we use the longest 2006-2008-2010 panel version available for taking advantage of the longest working history of individuals. We focus on the population of young working people, selecting the sample of people aged between 15 and 35 years. The choice of this high upper bound for age is due to the evidence that in Italy exit from school/entrance into the labour market is often delayed, and hence the category of young workers is wider than in other countries. The sample does not include immigrants (identified as those without Italian citizenship) and those working for the armed forces. Table 1 reports same basic characteristics of the sample.

The ISFOL-PLUS is a balanced panel of 6820 observations, $38 \%$ men and $62 \%$ women. In 2010 the survey has collected information about height and weight ${ }^{4}$, and also on some healthy behaviors of individuals such as sport practice and smoking. In particular, from height and weight we can calculate the BMI defined a persons's weight in kilograms divided by the square of her height in metres $\left(\mathrm{kg} / \mathrm{m}^{2}\right)$. Using the World Health Organisation (WHO)'s classification we classify an individual as

- Overweight if her/his BMI is greater than 25 and smaller than 30 ,

- Obese if her/his BMI is greater than or equal to 30

Accordingly we generate the dummy overweight, which is unity when $25<B M I<30$ and the dummy obesity, which is unity when $B M I \geq 30$.

Table 1 shows some descriptive statistics both for the overall and the estimation sample of height, weight and BMI. As we can see men are on average taller and fatter than women, with a BMI of 23.59 versus 21.67 of women, and a percentage of $23 \%$ with $B M I>25$ compared to $13 \%$ of women. Since we observe individual weight and height only for 2010 we have to restrict to this wave for estimation. As a result, more than half observations are lost in the estimation sample. Also, a small portion of this data loss is due to missing values in 2010. Interestingly enough, though, means and standard deviations in the estimation sample are very close to those of the complete sample, indicating that sample selection does not seem a serious concern for these data.

All the workers in the panel report their job satisfaction in each of the three years (2006, 2008 and 2010) both overall and in nine dimensions, available as answers to the following questions: "Overall, what is your level of satisfaction with respect to: 1) work environment (relationships with colleagues and superiors); 2) work organisation (timetable, shifts, overtime, holidays); 3) duties; 4) content of

\footnotetext{
${ }^{3}$ For a complete description of the survey see Mandrone (2012)

${ }^{4}$ Height and weight are self-reported, and as such (see Danubio et al. (2008)) can lead to misclassification of the prevalence of obesity since the participants overestimate or underestimate height, weight and/or both, and such misclassification vary according to gender and age.
} 
job; 5) protection against sickness, accident and industrial injury; 6) career perspectives; 7) pay; 8) competence and skill development; 9) job-stability". Responses are self-evaluations at four possible levels, which we have re-ordered homogeneously for increasing intensity as follows: low, medium-low, medium-high, high. The 'do not know' and 'not applicable' options have been eliminated from the sample.

As already remarked, we observe individual weight and height only for 2010, and so our empirical analysis is restricted to the 2010 wave of the ISFOL panel. Nonetheless, we try to exploit the panel information by including the group means of the time varying explanatory variables observed also in the previous waves in order to model correlated unobserved heterogeneity. Then, we use the available information on personal and family characteristics as explanatory variables. These variables comprise: sex, age, age squared, education (three groups: primary, secondary and tertiary education), region of residence (four macro-areas: North-West, North-East, Centre, South and Islands), three type of contracts (permanent employment, temporary employment, other temporary arrangements introduced by the recent labor market reforms), occupation (3 groups: high-medium-low skilled), sectoral membership (5 groups: agricultural, manufacturing, construction, trade and food, services) and a dummy variable that is unity if the individual has kids, the number of family components and its square.

Gross annual earnings are computed by ISFOL in order to make the information on work income homogeneous across contracts. In fact, in the original data, workers report annual or monthly wages according to the contract typology of their job. Unfortunately, due to the information available, no better homogeneous measures for labor earnings can be constructed.

\section{Empirical analysis}

Our research question is to examine the effects of overweight and obesity on job satisfaction (overall and in the nine aspects of job satisfaction provided by the ISFOL panel data). We also implement a wage equation to evaluate their effects on job earnings. All models include the same control variables: personal and family characteristics and, to control for correlated latent heterogeneity, the group means of the explanatory variables that are both time-varying and observed over the three waves. Caution should be exerted in interpreting our estimation results as causal effects, though, since the group means can accommodate only the time-invariant latent heterogeneity components that are correlated with a subset of control variables one that excludes overweight and obesity.

The estimation strategy is based on the Van Praag's probit OLS estimator (see Praag and i Carbonell 2004 and Praag and i Carbonell 2006 and, for an application to the ISFOL PLUS data, Bruno, Caroleo, and Dessy 2014 ). The estimation sample is of at most 2903 individuals with 1168 observations for males and 1735 for females. ${ }^{5}$

\footnotetext{
${ }^{5}$ The estimation sample slightly varies depending on the satisfaction variable. The actual sample sizes are reported in the Tables.
} 
Estimation results are in Tables 2-4. For each categorical variable we include the full set of dummies, excluding the reference category. So, the reference individual has a permanent contract in the agricultural sector, is high skilled, lives in the North-West of the country, does not have kids, has the lowest level of education and is of normal weight. Table 2 reports the estimation results for the regression model pooling males and females. It includes a gender dummy that is unity if the individual is a male. Tables 3 and 4 report results for the males and the females subsamples, respectively.

Focusing on the results from the pooled model in Table 2, we observe that the two measures of excess body fat exert almost always a negative impact, which is significant only in a few cases though: overweight individuals have significantly lower satisfaction over organization of work times, while obese individuals are significantly dissatisfied with their career opportunities and development of skills.

It seems likely that the sporadicalness of significant results in Table 2 may be the consequence of gender heterogeneity and, indeed, looking at the separate male and female subsamples shows that this is the case. Results for men in Table 3 show that the set of satisfaction aspects where being overweight exert a significantly negative impact, in addition to organization of work times, includes work environment, work duties, pay and skills. Obese men are significantly dissatisfied over development of skills and job stability only, and significantly satisfied over work duties, which is admittedly quite difficult to explain. From results in Table 4 we see that the being overweight is relatively less distressful for women than for men, while the reverse is true for obesity. Overweight women, in fact, are never significantly dissatisfied and, likewise obese men, are actually significantly satisfied over work duties. Obese women, instead, are dissatisfied over work duties and also over career opportunities.

Overall job satisfaction is not affected by either obesity or overweight for all the samples considered.

Heterogeneity between males and females is observed also for the satisfaction impact of another unhealthy behavior: smoking. Smoking has almost always a positive satisfaction impact for men, which is significant in the cases of satisfaction for work environment, organization of times, work duties and overall job-satisfaction. There is the exception of a significantly negative impact of smoking on the satisfaction over job safety (protection). For females smoking has never a significantly negative satisfaction impact. It has a significantly positive impact in the cases of satisfaction over content of job, job safety, job stability and overall job satisfaction.

Having kids has an ambiguous effect on the different aspects of job satisfaction, but it is more often significant and sizeable for women than for men. There is the notable exception, though, of a negatively significant overall job satisfaction impact for men where in contrast the same coefficient is insignificant for women. Low skilled males are significantly less satisfied than both high and medium skilled across many aspects of job satisfactions. Medium skilled females are often less satisfied than high skilled with the statistically significant exception of satisfaction over job safety. Coherently with what found in Bruno, Caroleo, and Dessy (2014), temporary workers are less satisfied than permanent workers. Sectoral membership does not seem to play a role for most aspects of men's job satisfaction. To the opposite female agricultural workers are the least satisfied over the two apsects of job content 
and career. Moreover, we do observe some regional effects but not important education effects.

We have also investigated the impact of the overweight and obesity variables on the gross income using the same set of controls and on the same samples as in the satisfaction equations. Results for these exercises are reported in Table 5 and constantly show insignificant effects for all the samples considered.

\section{Conclusions}

In this paper we have analysed empirically the relationship between measures of excess body fat (overweight and obesity) and labor market outcomes for young workers in Italy using the ISFOL-PLUS 2006-2008-2010 panel data. For the first time we have considered in particular as a measure of labor market outcome the quality of jobs evaluated through self-reported assessments on job satisfaction.

Considering nine aspects of job satisfaction we have found a general negative relationship between on the one hand obesity and overweight and on the other aspects of job satisfaction, with significant gender differences both about which is the most distressful condition, overweight or obesity, and about the aspects of job satisfaction that are mostly affected. While for men being overweight is the most distressful condition, for women is obesity. So, overweight men are dissatisfied over work environment, organization of work times, pay, and development of skills, where obese females are dissatisfied over work duties and career opportunities. Obese men are only dissatisfied over development of skills and job stability and overweight women are not dissatisfied at all. There is the interesting, although hard to explain, result that obese men and overweight women are more satisfied than their normal weight counterparts over burden of work duties. Overall job satisfaction is not affected by either obesity or overweight in either subsamples. Similarly the analysis on the gross-income effect of overweight and obesity does not yield significant results.

On a methodological note, from all the above findings we gather that considering aspects of job satisfaction as measures of labor market outcome improves significantly the analysis of the labor market consequences of obesity. Limiting the analysis to labor earnings, or also to overall job satisfaction, would have not uncovered any effect of an high BMI for Italian young workers. But some important effects are there, indeed, and become evident when the focus shifts to specific aspects of job satisfaction. Also the distinction between overweight and obesity seem relevant, as it is that between young men and women.

If, according to the recent European directions, a good quality of jobs should be a goal to reach in all countries, the analysis of the Italian case shows that attention should be given to the problem of obesity for young people, although further research is needed for exploring the causal relationship between BMI and labor market outcomes. 


\section{References}

A. Booth, M. Francesconi and J. Frank. 2002. "Temporary jobs: stepping stones or dead ends?" Economic Journal 112 (480):F189-F213.

Addabbo, T. and G. Solinas. 2012. "Non-standard employment and quality of work: toward new forms of measurement." In Non-standard employment and quality of work: the case of Italy, edited by T. Addabbo and G. Solinas. Heidelberg: Springer Verlag.

Bardasi, E. and M. Francesconi. 2004. "The impat of atypical employment on individual wellbeing: evidence from a panel of British workers." Social Science and Medicine 58 (9):1671-1688.

Biddle, J. E. and D. S. Hamermesh. 1994. "Beauty and the labor market." American Economic Review 84 (5):1174-1194.

- 1998. "Beauty, productivity and discrimination: lawyers' looks and lucre." Journal of Labor Economics 16 (1):172-201.

Brunello, G. and B. d'Hombres. 2007. "Does body weight affect wages: evidence from Europe." Economics and Human Biology 5:1-19.

Bruno, G. S. F., F. E. Caroleo, and O. Dessy. 2014. "Temporary Contracts and Young Workers' Job Satisfaction in Italy." In Disadvantaged Workers: Empirical Evidence and Labour Policies, edited by M. A. Malo and D. Sciulli, AIEL Series in Labour Economics. Springer.

Caliendo, M. and M. Gehrsitz. 2014. "Obesity and the labor market: a fresh look at the weight penalty." DIW W. P. 631 .

Cawley, J. 2000. "Body Weight and Women's Labor Market Outcomes." NBER, Working Paper 7841

—. 2004. "The impact of obesity on wages." The Journal of Human Resources 39 (2):451-474.

Danubio, M. E., G. Miranda, M. G. Vinciguerra, E. Vecchi, and F. Rufo. 2008. "Comparison of selfreported and measured height and weight: Implications for obesity research among young adults." Economics and Human Biology Human Biology 6 (1):181-190.

de Graaf-Zijl, M. 2012. "Job satisfaction and contingent employment." De Economist 160:197-218.

Elder, S. 2009. ILO school-to-work transitions. Geneva: International Labour Office.

Eurofound. 2007. Job satisfaction and labor market mobility. Dublin: Eurofund.

. 2012. Trends in job quality in Europe. Luxembourg: Publications Office of the European Union. 
Freeman, R. 1978. "Job saisfaction as an economic variable." American Economic Review 68:135-141.

Green, C. and J. S. Heywood. 2011. "Flexible contracts and subjective well-being." Economic Inquiry 49:716-729.

Greve, J. 2005. "Obesity and Labor Market Outcomes: New Danish Evidence." mimeo .

Hamermesh, D. 1997. "Economic aspects of job satisfaction." In Essays in labor market analysis, edited by O. Ashenfelter and W. Oates. Oxford: Wiley.

IOTF. 2002. Obesity in Europe. The case for action, International Obesity Task Force and European Association for the Study of Obesity.

. 2003. Obesity in Europe 2. Waiting for a green light for health? Europe at the crossroads for diet and disease.

J. Cawley, M. Grabka and D. Lillard. 2005. "A Comparison of the Relationship between Obesity and Earnings in the U.S. and Germany." Journal of Applied Social Science Studies (Schmollers Jahrbuch) 125:119-129.

Mandrone, E. 2012. Labour Economics: PLUS Empirical Studies. Temi e Strumenti. Ediguida.

Morris, S. 2005. "Body Mass Index and Occupational Attainment." Tanaka Business School Discussion Papers: $T B S / D P 05 / 41$.

. 2006. "Body Mass Index and Occupational Attainment." Journal of Health Economics 25:347364.

Oreffice, S. and C. Quintana-Domenque. 2014. "Atttractiveness, anthropometry or both? Their relationship and role in economic research." IZA, Discussion Paper No. 8527 .

Oswald, A. J. 1997. "Happiness and economic performance." Economic Journal 107 (445):1815-1831.

P. Lundborg, S. Hojgard, K. Bolin and B. Lindgren. 2007. "Obesity and Occupational Attainment among the 50+ of Europe." Advances in Health Economics and Health Services Research 17.

Praag, B. M. S. Van and A. Ferrer i Carbonell. 2004. Happiness quantified: A satisfaction calculus approach. Oxford: UK.: Oxford Universty Press.

—. 2006. "An almost integration-free approach to ordered response models." D. P. 2006-047/3., Tibergen Institute.

Sargent, J. and B. Blanchflower. 1994. "Obesity and Stature in Adolescence and Earnings in Young Adulthood. Analysis of a British Birth Cohort." Archives of Pediatrics and Adolescent Medicine 148:681-687. 
Sarlio-Lahteenkorva, S. and E. Lahelma. 1999. "The Association of Body Mass Index with Social and Economic Disadvantage in Women and Men." International Journal of Epidemiology 28:445-449.

Sousa, S. 2005. "Does size matter? A propensity score approach to the effect of BMI on labour market outcomes." mimeo .

V. Atella, N. Pace and D. Vuri. 2008. "Are employers discriminating with respect to weight? European evidence using quantile regression." Economics and Human Biology 6:305-329.

Villar, J. Garcia and C. Quintana-Domeque. 2006. The economics of obesity, Advances in health economics and health services research, vol. 17, chap. Obesity, employment and wages in Europe. Emerald Group Publishing Limited, 187-217.

WHO. 2003. "Diet, nutrition, and the prevention of chronic disease." World Health Organization Technical Report 916. 


\section{APPENDIX}

Table 1: Descriptive Statistics of the ISFOL-PLUS 2006-2008-2010 panel

\begin{tabular}{|c|c|c|c|c|c|c|c|c|c|c|c|c|}
\hline \multicolumn{7}{|c|}{ TOTAL SAMPLE } & \multicolumn{6}{|c|}{ ESTIMATION SAMPLE } \\
\hline & Males & & Females & & Total & & Males & & Females & & Total & \\
\hline & Freq. & Percent & Freq. & Percent & Freq. & Percent & Freq. & Percent & Freq. & Percent & Freq. & Percent \\
\hline Observations & 2,583 & 37.87 & 4,237 & 62.13 & 6,820 & 100 & 1168 & 40.2 & 1735 & 59.8 & 2903 & 100 \\
\hline & Mean & $\begin{array}{l}\text { Std. } \\
\text { Dev. }\end{array}$ & Mean & $\begin{array}{l}\text { Std. } \\
\text { Dev. }\end{array}$ & Mean & $\begin{array}{l}\text { Std. } \\
\text { Dev. }\end{array}$ & Mean & $\begin{array}{l}\text { Std. } \\
\text { Dev. }\end{array}$ & Mean & $\begin{array}{l}\text { Std. } \\
\text { Dev. }\end{array}$ & Mean & $\begin{array}{l}\text { Std. } \\
\text { Dev. }\end{array}$ \\
\hline Height & 178.07 & 6.76 & 164.84 & 6.41 & 169.85 & 9.16 & 177.98 & 6.88 & 164.87 & 6.30 & 170.15 & 9.17 \\
\hline Weight & 74.88 & 11.28 & 58.91 & 10.19 & 64.95 & 13.13 & 75.35 & 11.15 & 58.62 & 10.11 & 65.35 & 13.36 \\
\hline BMI & 23.59 & 3.13 & 21.67 & 3.46 & 22.39 & 3.46 & 23.77 & 3.12 & 21.55 & 3.45 & 22.44 & 3.50 \\
\hline BMI $>25$ & 0.23 & 0.42 & 0.13 & 0.34 & 0.17 & 0.37 & 0.26 & 0.44 & 0.12 & 0.33 & 0.18 & 0.38 \\
\hline
\end{tabular}


Table 2: Aspects of Job Satisfaction - Total sample - Probit OLS estimates

\begin{tabular}{|c|c|c|c|c|c|c|c|c|c|c|}
\hline SATISFACTION & environment & organisation & duties & content & protection & career & pay & skills & stability & overall \\
\hline \multirow[t]{2}{*}{ Male } & $0.155^{*}$ & 0.0247 & -0.00114 & $0.198 * *$ & 0.0627 & $0.359 * * *$ & $0.270 * * *$ & 0.0994 & $0.271 * * *$ & $0.269 * * *$ \\
\hline & $(0.0815)$ & $(0.0883)$ & $(0.0852)$ & $(0.0908)$ & $(0.0769)$ & $(0.0818)$ & $(0.0857)$ & $(0.0889)$ & $(0.0779)$ & $(0.0935)$ \\
\hline \multirow[t]{2}{*}{$25<\mathrm{BMI}<30$} & -0.0549 & $-0.192 * * *$ & -0.00374 & -0.0681 & -0.0250 & -0.123 & -0.0882 & -0.112 & -0.0801 & -0.0608 \\
\hline & $(0.0765)$ & $(0.0739)$ & $(0.0829)$ & $(0.0845)$ & $(0.0709)$ & $(0.0802)$ & $(0.0788)$ & $(0.0835)$ & $(0.0726)$ & $(0.0817)$ \\
\hline \multirow[t]{2}{*}{$\mathrm{BMI} \geq 30$} & -0.0975 & -0.0134 & -0.278 & 0.0317 & -0.0782 & $-0.404 * * *$ & -0.177 & $-0.228 *$ & -0.163 & -0.191 \\
\hline & $(0.184)$ & $(0.169)$ & $(0.223)$ & $(0.186)$ & $(0.159)$ & $(0.137)$ & $(0.191)$ & $(0.125)$ & $(0.153)$ & $(0.124)$ \\
\hline \multirow[t]{2}{*}{ Smoke } & 0.0865 & $0.189 * * *$ & 0.0806 & $0.183 * *$ & -0.00579 & $0.111^{*}$ & $0.113^{*}$ & 0.0741 & $0.104^{*}$ & $0.201 * * *$ \\
\hline & $(0.0628)$ & $(0.0666)$ & $(0.0715)$ & $(0.0720)$ & $(0.0564)$ & $(0.0626)$ & $(0.0637)$ & $(0.0595)$ & $(0.0572)$ & $(0.0657)$ \\
\hline \multirow[t]{2}{*}{ Age } & $7.347^{*}$ & 6.221 & 0.346 & 6.021 & $14.88 * * *$ & 0.659 & $-5.207 *$ & $-9.888 * * *$ & 1.144 & -1.811 \\
\hline & $(4.223)$ & $(4.687)$ & $(5.882)$ & $(3.801)$ & $(3.616)$ & $(7.070)$ & $(3.130)$ & $(3.580)$ & $(2.193)$ & $(2.075)$ \\
\hline \multirow[t]{2}{*}{ Age squared } & $-0.134 *$ & -0.112 & 0.00416 & $-0.112^{*}$ & $-0.268 * * *$ & -0.0298 & 0.0660 & $0.160 * *$ & -0.0263 & 0.0307 \\
\hline & $(0.0753)$ & $(0.0844)$ & $(0.104)$ & $(0.0678)$ & $(0.0643)$ & $(0.125)$ & $(0.0576)$ & $(0.0648)$ & $(0.0439)$ & $(0.0407)$ \\
\hline \multirow[t]{2}{*}{ Kids } & 0.847 & $4,719^{*}$ & $-5.529 * * *$ & $-2.981 * * *$ & $-5.171 * * *$ & -832.1 & $-6.031 * * *$ & $-1,779$ & -0.0362 & -0.509 \\
\hline & $(0.701)$ & $(2,754)$ & $(1.171)$ & $(0.624)$ & $(0.485)$ & $(2,518)$ & $(0.579)$ & $(2,298)$ & $(0.572)$ & $(0.557)$ \\
\hline \multirow[t]{2}{*}{ \# family comp. } & -0.0730 & -0.195 & 0.137 & -0.339 & 0.180 & -0.313 & 0.130 & -0.0372 & 0.0550 & -0.254 \\
\hline & $(0.208)$ & $(0.211)$ & $(0.238)$ & $(0.215)$ & $(0.183)$ & $(0.241)$ & $(0.225)$ & $(0.257)$ & $(0.183)$ & $(0.223)$ \\
\hline \multirow[t]{2}{*}{ \# family comp. sq. } & 0.0149 & 0.0263 & -0.0129 & $0.0549 *$ & -0.0345 & 0.0366 & -0.0285 & -0.00770 & -0.0182 & 0.0389 \\
\hline & $(0.0321)$ & $(0.0318)$ & $(0.0367)$ & $(0.0318)$ & $(0.0271)$ & $(0.0354)$ & $(0.0341)$ & $(0.0392)$ & $(0.0279)$ & $(0.0349)$ \\
\hline \multirow{2}{*}{$\begin{array}{l}\text { Temporary } \\
\text { employee }\end{array}$} & $-0.257^{*}$ & $-0.360 * *$ & -0.124 & -0.114 & -0.0281 & -0.119 & -0.191 & -0.0724 & $-0.562 * * *$ & -0.178 \\
\hline & $(0.136)$ & $(0.141)$ & $(0.147)$ & $(0.144)$ & $(0.121)$ & $(0.135)$ & $(0.123)$ & $(0.131)$ & $(0.102)$ & $(0.153)$ \\
\hline \multirow{2}{*}{$\begin{array}{l}\text { Temporary } \\
\text { other arrangem. }\end{array}$} & -0.0492 & -0.210 & 0.154 & -0.0353 & $-0.435^{*}$ & $-0.469^{*}$ & $-0.443 *$ & -0.160 & $-1.368 * * *$ & $-0.413 *$ \\
\hline & $(0.212)$ & $(0.243)$ & $(0.249)$ & $(0.276)$ & $(0.238)$ & $(0.256)$ & $(0.231)$ & $(0.293)$ & $(0.232)$ & $(0.213)$ \\
\hline \multirow[t]{2}{*}{ North-East } & $2.101 * * *$ & -0.0899 & 1.019 & $1.975 * * *$ & $1.341 * * *$ & -0.892 & 0.275 & 0.722 & -0.216 & 0.0685 \\
\hline & $(0.609)$ & $(0.713)$ & $(0.767)$ & $(0.367)$ & $(0.338)$ & $(0.567)$ & $(0.450)$ & $(0.460)$ & $(0.981)$ & $(0.228)$ \\
\hline \multirow[t]{2}{*}{ Centre } & 0.499 & 1.262 & 0.824 & 0.574 & 0.270 & -1.051 & -0.648 & 0.447 & -0.105 & 0.155 \\
\hline & $(0.618)$ & $(0.886)$ & $(0.714)$ & $(0.594)$ & $(0.626)$ & $(0.993)$ & $(0.796)$ & $(0.619)$ & $(0.724)$ & $(0.846)$ \\
\hline \multirow[t]{2}{*}{ South-Islands } & 0.707 & 1.002 & $1.081^{*}$ & $0.970 * *$ & -0.210 & 0.111 & -0.0537 & 0.579 & $0.767 *$ & 0.502 \\
\hline & $(0.489)$ & $(0.663)$ & $(0.634)$ & $(0.393)$ & $(0.566)$ & $(0.410)$ & $(0.391)$ & $(0.368)$ & $(0.434)$ & $(0.859)$ \\
\hline \multirow{2}{*}{$\begin{array}{l}\text { Secondary } \\
\text { education }\end{array}$} & -0.147 & 0.107 & -0.0942 & -0.174 & -0.00907 & 0.231 & 0.0892 & $0.236^{* *}$ & $0.275^{* *}$ & -0.0814 \\
\hline & $(0.170)$ & $(0.175)$ & $(0.180)$ & $(0.182)$ & $(0.152)$ & $(0.156)$ & $(0.141)$ & $(0.119)$ & $(0.135)$ & $(0.186)$ \\
\hline \multirow{2}{*}{$\begin{array}{l}\text { Tertiary } \\
\text { education }\end{array}$} & -0.0862 & -0.00752 & -0.255 & $-0.386^{*}$ & -0.115 & 0.183 & 0.225 & 0.136 & 0.0401 & $-0.386^{*}$ \\
\hline & $(0.217)$ & $(0.217)$ & $(0.225)$ & $(0.229)$ & $(0.196)$ & $(0.200)$ & $(0.188)$ & $(0.188)$ & $(0.193)$ & $(0.215)$ \\
\hline \multirow[t]{2}{*}{ Medium skilled } & 0.00963 & 0.0272 & -0.00645 & $-0.110^{*}$ & 0.0498 & $-0.128^{*}$ & 0.0521 & $-0.236 * * *$ & 0.0529 & -0.0430 \\
\hline & $(0.0571)$ & $(0.0577)$ & $(0.0637)$ & $(0.0637)$ & $(0.0640)$ & $(0.0663)$ & $(0.0629)$ & $(0.0634)$ & $(0.0538)$ & $(0.0574)$ \\
\hline \multirow[t]{2}{*}{ Low skilled } & -0.134 & -0.0890 & -0.0961 & $-0.316 * * *$ & -0.0948 & $-0.367 * * *$ & -0.127 & $-0.420 * * *$ & 0.0117 & $-0.408 * * *$ \\
\hline & $(0.107)$ & $(0.113)$ & $(0.107)$ & $(0.106)$ & $(0.0944)$ & $(0.106)$ & $(0.102)$ & $(0.108)$ & $(0.0983)$ & $(0.113)$ \\
\hline \multirow[t]{2}{*}{ Manufacturing } & -0.0385 & 0.121 & 0.255 & $0.475 * * *$ & 0.118 & $0.434 * *$ & -0.224 & 0.0776 & -0.183 & -0.362 \\
\hline & $(0.178)$ & $(0.164)$ & $(0.207)$ & $(0.182)$ & $(0.176)$ & $(0.185)$ & $(0.231)$ & $(0.228)$ & $(0.182)$ & $(0.356)$ \\
\hline Construction & 0.0573 & 0.191 & 0.135 & $0.492 * *$ & -0.0562 & $0.849 * * *$ & 0.00171 & 0.198 & -0.0233 & -0.152 \\
\hline & $(0.205)$ & $(0.185)$ & $(0.240)$ & $(0.226)$ & $(0.211)$ & $(0.227)$ & $(0.249)$ & $(0.243)$ & $(0.201)$ & $(0.366)$ \\
\hline Trade and food & -0.145 & -0.0975 & 0.271 & $0.342 *$ & -0.171 & $0.425 * *$ & -0.263 & 0.0491 & 0.0789 & -0.321 \\
\hline & $(0.171)$ & $(0.153)$ & $(0.206)$ & $(0.181)$ & $(0.174)$ & $(0.185)$ & $(0.225)$ & $(0.225)$ & $(0.165)$ & $(0.337)$ \\
\hline Services & -0.0779 & 0.0654 & 0.187 & $0.437 * *$ & -0.106 & $0.519 * * *$ & -0.245 & 0.0833 & 0.0285 & -0.298 \\
\hline & $(0.166)$ & $(0.138)$ & $(0.201)$ & $(0.174)$ & $(0.170)$ & $(0.177)$ & $(0.223)$ & $(0.224)$ & $(0.163)$ & $(0.340)$ \\
\hline Constant & -12.23 & -11.55 & 0.749 & -11.21 & $-29.85 * * *$ & -1.963 & $11.82 *$ & $19.14 * *$ & -0.595 & 6.535 \\
\hline & $(8.550)$ & $(9.457)$ & (11.82) & $(7.770)$ & $(7.411)$ & (14.19) & $(6.550)$ & $(7.467)$ & (4.686) & $(4.509)$ \\
\hline Observations & 2,884 & 2,888 & 2,886 & 2,896 & 2,855 & 2,843 & 2,870 & 2,863 & 2,856 & 2,903 \\
\hline R-squared & 0.074 & 0.074 & 0.049 & 0.096 & 0.075 & 0.110 & 0.102 & 0.097 & 0.148 & 0.096 \\
\hline $\begin{array}{l}\text { Number } \\
\text { reference } \\
\text { kids, is } h \\
\text { included } \\
\text { Robust } \mathrm{s}\end{array}$ & $\begin{array}{l}\text { killed and has } \\
1 \text { regressions } \\
\text { ard errors in } p\end{array}$ & lowest leve & education. & e group me & $\begin{array}{l}\text { count varia } \\
t \text { in the agri } \\
\text { of the time }\end{array}$ & $\begin{array}{l}\text { All the o } \\
\text { tural sector } \\
\text { rrying regre } \\
\text { table). }\end{array}$ & $\begin{array}{l}\text { r regressor } \\
\text { ho lives in } \\
\text { ors observe }\end{array}$ & $\begin{array}{l}\text { e binary in } \\
\text { North-W } \\
\text { ver the thr }\end{array}$ & $\begin{array}{l}\text { ators. The } \\
\text { does not hi } \\
\text { vaves are }\end{array}$ & \\
\hline
\end{tabular}


Table 3: Aspects of Job Satisfaction - Males sample - Probit OLS estimates

\begin{tabular}{|c|c|c|c|c|c|c|c|c|c|c|}
\hline SATISFACTION & environment & organisation & duties & content & protection & career & pay & skills & stability & overall \\
\hline \multirow[t]{2}{*}{$25<\mathrm{BMI}<30$} & $-0.155^{*}$ & $-0.245^{* * *}$ & $-0.174^{*}$ & -0.107 & -0.0803 & -0.132 & $-0.177 *$ & $-0.216^{* *}$ & -0.0901 & -0.0978 \\
\hline & $(0.0925)$ & $(0.0849)$ & $(0.0988)$ & $(0.0973)$ & $(0.0869)$ & $(0.107)$ & $(0.0959)$ & $(0.101)$ & $(0.0845)$ & $(0.101)$ \\
\hline \multirow[t]{2}{*}{$\mathrm{BMI} \geq 30$} & 0.00577 & 0.283 & $0.463 * *$ & 0.172 & -0.291 & -0.293 & -0.236 & $-0.311 * *$ & $-0.369 *$ & -0.0830 \\
\hline & $(0.221)$ & $(0.197)$ & $(0.223)$ & $(0.175)$ & $(0.240)$ & $(0.179)$ & $(0.362)$ & $(0.144)$ & $(0.203)$ & $(0.175)$ \\
\hline \multirow[t]{2}{*}{ Smoke } & $0.157^{*}$ & $0.274 * * *$ & $0.203 * *$ & 0.0713 & $-0.155^{*}$ & 0.110 & 0.0841 & 0.107 & 0.0315 & $0.151^{*}$ \\
\hline & $(0.0879)$ & $(0.0880)$ & $(0.0989)$ & $(0.0948)$ & $(0.0801)$ & $(0.0930)$ & $(0.0844)$ & $(0.0840)$ & $(0.0784)$ & $(0.0898)$ \\
\hline \multirow[t]{2}{*}{ Age } & $52.89 * * *$ & $41.36 * * *$ & $61.06 * * *$ & $46.04 * * *$ & $49.27 * * *$ & $-64.82 * * *$ & $31.28 * * *$ & $-39.64 * * *$ & -0.252 & 12.49 \\
\hline & $(9.410)$ & $(10.15)$ & $(10.58)$ & $(9.368)$ & $(8.172)$ & $(10.43)$ & $(9.616)$ & $(9.983)$ & $(8.809)$ & $(10.05)$ \\
\hline \multirow[t]{2}{*}{ Age squared } & $-0.885^{* * *}$ & $-0.680 * * *$ & $-0.966 * * *$ & $-0.778 * * *$ & $-0.823 * * *$ & $1.034 * * *$ & $-0.522 * * *$ & $0.634 * * *$ & 0.00303 & -0.204 \\
\hline & $(0.152)$ & $(0.164)$ & $(0.171)$ & $(0.151)$ & $(0.132)$ & $(0.168)$ & $(0.155)$ & $(0.160)$ & $(0.142)$ & $(0.162)$ \\
\hline \multirow[t]{2}{*}{ Kids } & $-1.431 * * *$ & -1.374 & 1.087 & -0.274 & $0.692 *$ & 2.609 & $-1.318 * * *$ & -0.632 & $-1.352 * * *$ & $-1.866 * * *$ \\
\hline & $(0.396)$ & (1.499) & $(1.588)$ & $(0.402)$ & $(0.366)$ & $(2.092)$ & $(0.393)$ & $(1.921)$ & $(0.327)$ & $(0.511)$ \\
\hline \multirow[t]{2}{*}{ \# family comp. } & -0.357 & -0.367 & 0.162 & -0.412 & 0.312 & -0.282 & 0.215 & -0.121 & 0.0221 & -0.371 \\
\hline & $(0.299)$ & $(0.301)$ & $(0.340)$ & $(0.318)$ & $(0.266)$ & $(0.355)$ & $(0.323)$ & $(0.337)$ & $(0.267)$ & $(0.337)$ \\
\hline \multirow[t]{2}{*}{ \# family comp. sq. } & 0.0549 & 0.0686 & -0.0204 & $0.0830 *$ & -0.0515 & 0.0381 & -0.0450 & -0.00506 & -0.0122 & 0.0600 \\
\hline & $(0.0497)$ & $(0.0481)$ & $(0.0569)$ & $(0.0497)$ & $(0.0411)$ & $(0.0545)$ & $(0.0542)$ & $(0.0564)$ & $(0.0440)$ & $(0.0563)$ \\
\hline \multirow{2}{*}{$\begin{array}{l}\text { Temporary } \\
\text { employee }\end{array}$} & -0.203 & $-0.452 * *$ & -0.101 & -0.251 & -0.0655 & -0.106 & $-0.386^{* *}$ & -0.154 & $-0.464 * * *$ & -0.139 \\
\hline & $(0.218)$ & $(0.218)$ & $(0.241)$ & $(0.236)$ & $(0.168)$ & $(0.214)$ & $(0.176)$ & $(0.196)$ & $(0.149)$ & $(0.229)$ \\
\hline \multirow{2}{*}{$\begin{array}{l}\text { Temporary } \\
\text { other arrangem. }\end{array}$} & 0.205 & 0.103 & 0.479 & 0.0481 & -0.0630 & -0.0165 & -0.316 & 0.238 & $-1.776 * * *$ & -0.0301 \\
\hline & $(0.250)$ & $(0.303)$ & $(0.345)$ & $(0.430)$ & $(0.331)$ & $(0.416)$ & $(0.372)$ & $(0.466)$ & $(0.307)$ & $(0.297)$ \\
\hline \multirow[t]{2}{*}{ North-East } & 1.406 & -1.123 & -2.003 & $3.317 * * *$ & 0.201 & -1.815 & -1.441 & 1.706 & $-2.893^{*}$ & 0.273 \\
\hline & $(1.486)$ & $(0.848)$ & (1.633) & $(0.727)$ & $(0.922)$ & $(1.442)$ & $(1.525)$ & $(1.512)$ & $(1.517)$ & $(0.586)$ \\
\hline \multirow[t]{2}{*}{ Centre } & -1.563 & -0.0708 & -0.851 & -0.138 & -0.616 & $-1.863 * * *$ & -1.556 & 0.266 & $-1.875^{*}$ & 0.311 \\
\hline & $(1.031)$ & $(1.000)$ & $(1.322)$ & $(1.448)$ & (1.087) & $(0.649)$ & $(0.981)$ & $(1.328)$ & $(1.035)$ & $(1.010)$ \\
\hline \multirow[t]{2}{*}{ South-Islands } & 0.739 & $2.267 * * *$ & $2.162 * * *$ & $1.569 * * *$ & 0.144 & 0.536 & 0.0327 & 0.756 & $1.651 * * *$ & 1.712 \\
\hline & $(0.704)$ & $(0.679)$ & $(0.724)$ & $(0.547)$ & $(1.137)$ & $(0.586)$ & $(0.706)$ & $(0.560)$ & $(0.297)$ & $(1.227)$ \\
\hline \multirow{2}{*}{$\begin{array}{l}\text { Secondary } \\
\text { education }\end{array}$} & -0.141 & 0.208 & -0.0163 & -0.163 & 0.0314 & $0.394 *$ & 0.221 & 0.184 & 0.161 & -0.315 \\
\hline & $(0.224)$ & $(0.234)$ & $(0.245)$ & $(0.241)$ & $(0.188)$ & $(0.214)$ & $(0.189)$ & $(0.148)$ & $(0.171)$ & $(0.222)$ \\
\hline \multirow{2}{*}{$\begin{array}{l}\text { Tertiary } \\
\text { education }\end{array}$} & -0.0462 & 0.252 & -0.0861 & -0.376 & 0.131 & 0.322 & $0.657 * *$ & 0.0496 & 0.227 & $-0.526^{*}$ \\
\hline & $(0.354)$ & $(0.319)$ & $(0.354)$ & $(0.353)$ & $(0.297)$ & $(0.291)$ & $(0.257)$ & $(0.312)$ & $(0.274)$ & $(0.295)$ \\
\hline \multirow[t]{2}{*}{ Medium skilled } & 0.0960 & 0.0644 & 0.0960 & 0.00800 & -0.124 & -0.123 & 0.0290 & $-0.172 *$ & 0.103 & -0.0133 \\
\hline & $(0.0906)$ & $(0.0854)$ & $(0.0993)$ & $(0.0980)$ & $(0.0951)$ & $(0.107)$ & $(0.0958)$ & $(0.0981)$ & $(0.0750)$ & $(0.0942)$ \\
\hline \multirow[t]{2}{*}{ Low skilled } & -0.159 & -0.0584 & -0.0849 & $-0.324 * *$ & $-0.317 * * *$ & $-0.554 * * *$ & $-0.222 * *$ & $-0.406 * * *$ & 0.141 & $-0.438 * * *$ \\
\hline & $(0.125)$ & $(0.125)$ & $(0.139)$ & $(0.136)$ & $(0.107)$ & $(0.128)$ & $(0.112)$ & $(0.123)$ & $(0.112)$ & $(0.131)$ \\
\hline \multirow[t]{2}{*}{ Manufacturing } & 0.000516 & 0.194 & 0.0957 & 0.306 & -0.00554 & 0.406 & -0.385 & -0.0769 & 0.213 & -0.411 \\
\hline & $(0.267)$ & $(0.196)$ & $(0.268)$ & $(0.243)$ & $(0.259)$ & $(0.253)$ & $(0.290)$ & $(0.304)$ & $(0.168)$ & $(0.317)$ \\
\hline \multirow[t]{2}{*}{ Construction } & -0.00808 & 0.184 & -0.0610 & 0.225 & -0.310 & $0.715^{* *}$ & -0.251 & 0.0251 & 0.179 & -0.367 \\
\hline & $(0.293)$ & $(0.241)$ & $(0.297)$ & $(0.288)$ & $(0.292)$ & $(0.295)$ & $(0.304)$ & $(0.315)$ & $(0.214)$ & $(0.339)$ \\
\hline \multirow[t]{2}{*}{ Trade and food } & -0.289 & -0.114 & 0.0612 & 0.103 & -0.296 & 0.336 & -0.439 & -0.0605 & $0.413 * *$ & -0.492 \\
\hline & $(0.262)$ & $(0.215)$ & $(0.266)$ & $(0.242)$ & $(0.263)$ & $(0.273)$ & $(0.292)$ & $(0.305)$ & $(0.165)$ & $(0.309)$ \\
\hline Services & -0.157 & 0.0913 & -0.0218 & 0.185 & -0.238 & $0.468 *$ & -0.460 & -0.0398 & $0.364 * *$ & -0.401 \\
\hline & $(0.269)$ & $(0.193)$ & $(0.268)$ & $(0.246)$ & $(0.259)$ & $(0.259)$ & $(0.285)$ & $(0.303)$ & $(0.159)$ & $(0.316)$ \\
\hline Constant & $-101.8^{* * *}$ & $-82.32 * * *$ & $-119.2 * * *$ & $-88.47 * * *$ & $-96.03 * * *$ & $125.9 * * *$ & $-61.56 * * *$ & $76.90 * * *$ & 1.599 & -21.43 \\
\hline & $(18.11)$ & $(19.51)$ & $(20.31)$ & $(17.97)$ & $(16.20)$ & (19.98) & (18.44) & $(19.35)$ & $(17.26)$ & (19.35) \\
\hline Observations & 1,163 & 1,160 & 1,164 & 1,166 & 1,150 & 1,152 & 1,157 & 1,153 & 1,147 & 1,168 \\
\hline R-squared & 0.119 & 0.133 & 0.104 & 0.132 & 0.102 & 0.131 & 0.155 & 0.155 & 0.217 & 0.124 \\
\hline
\end{tabular}

Number of family components (and its square) and age (and its square) are count variables. All the other regressors are binary indicators. The reference individual is of normal weight, has a permanent contract in the agricultural sector, is high skilled, lives in the North-West, does not have kids, and has the lowest level of education. The group means of the time-varying regressors observed over the three waves are included in all regressions (the corresponding coefficient estimates are not reported in the table).

Robust standard errors in parentheses: $* * * \mathrm{p}<0.01, * * \mathrm{p}<0.05, * \mathrm{p}<0.1$ 
Table 4: Aspects of Job Satisfaction - Females sample - Probit OLS estimates

\begin{tabular}{|c|c|c|c|c|c|c|c|c|c|c|}
\hline SATISFACTION & environment & organisation & duties & content & protection & career & pay & skills & stability & overall \\
\hline \multirow[t]{2}{*}{$25<\mathrm{BMI}<30$} & 0.0793 & -0.0456 & $0.262 * *$ & 0.0152 & 0.0726 & -0.155 & 0.0495 & 0.156 & -0.0598 & 0.000607 \\
\hline & $(0.128)$ & $(0.132)$ & $(0.116)$ & $(0.127)$ & $(0.106)$ & $(0.103)$ & $(0.123)$ & $(0.121)$ & $(0.112)$ & $(0.105)$ \\
\hline \multirow[t]{2}{*}{$\mathrm{BMI} \geq 30$} & -0.134 & -0.211 & $-0.696 * * *$ & -0.0284 & 0.0157 & $-0.543 * * *$ & -0.0868 & -0.0652 & 0.0823 & -0.220 \\
\hline & $(0.268)$ & $(0.229)$ & $(0.239)$ & $(0.300)$ & $(0.206)$ & $(0.207)$ & $(0.234)$ & $(0.200)$ & $(0.187)$ & $(0.157)$ \\
\hline \multirow[t]{2}{*}{ Smoke } & 0.0447 & 0.0966 & -0.0130 & $0.278 * * *$ & $0.133^{*}$ & 0.0541 & 0.106 & 0.0737 & $0.135^{*}$ & $0.209 * * *$ \\
\hline & $(0.0808)$ & $(0.0888)$ & $(0.0781)$ & $(0.0829)$ & $(0.0782)$ & $(0.0781)$ & $(0.0828)$ & $(0.0796)$ & $(0.0751)$ & $(0.0698)$ \\
\hline Age & - & - & - & - & - & - & - & - & - & - \\
\hline \multirow[t]{2}{*}{ Age squared } & 0.00664 & -0.000526 & -0.00161 & 0.00287 & $0.0276^{* * *}$ & -0.000939 & $0.0412 * * *$ & $0.0342 * * *$ & 0.00127 & -0.00697 \\
\hline & $(0.00437)$ & $(0.00438)$ & $(0.00433)$ & $(0.00431)$ & $(0.00422)$ & $(0.00429)$ & $(0.00439)$ & $(0.00406)$ & $(0.00418)$ & $(0.00448)$ \\
\hline \multirow[t]{2}{*}{ Kids } & $-2.310 * * *$ & 4,060 & $1.216 * *$ & -231.9 & $-4.591 * * *$ & -281.3 & $-4.953 * * *$ & $-4.151 * * *$ & $2.215^{* * *}$ & 0.231 \\
\hline & $(0.531)$ & $(7,922)$ & $(0.514)$ & $(8,014)$ & $(0.502)$ & $(6,861)$ & $(0.510)$ & $(0.485)$ & $(0.501)$ & $(0.448)$ \\
\hline \multirow[t]{2}{*}{ \# family comp. } & $0.387 *$ & -0.0527 & 0.236 & -0.240 & 0.112 & -0.323 & 0.0508 & 0.224 & 0.228 & -0.0316 \\
\hline & $(0.211)$ & $(0.219)$ & $(0.251)$ & $(0.227)$ & $(0.207)$ & $(0.200)$ & $(0.212)$ & $(0.185)$ & $(0.200)$ & $(0.177)$ \\
\hline \multirow[t]{2}{*}{ \# family comp. sq. } & $-0.0509 *$ & -0.00628 & -0.0241 & 0.0197 & -0.0241 & 0.0311 & -0.0188 & -0.0328 & -0.0442 & -0.00245 \\
\hline & $(0.0303)$ & $(0.0313)$ & $(0.0355)$ & $(0.0316)$ & $(0.0288)$ & $(0.0290)$ & $(0.0297)$ & $(0.0262)$ & $(0.0281)$ & $(0.0262)$ \\
\hline \multirow{2}{*}{$\begin{array}{l}\text { Temporary } \\
\text { employee }\end{array}$} & $-0.293 * *$ & -0.192 & -0.0636 & 0.126 & 0.147 & -0.0773 & 0.0406 & 0.0565 & $-0.743 * * *$ & $-0.268 * *$ \\
\hline & $(0.143)$ & $(0.168)$ & $(0.144)$ & $(0.130)$ & $(0.152)$ & $(0.143)$ & $(0.154)$ & $(0.157)$ & $(0.143)$ & $(0.133)$ \\
\hline \multirow{2}{*}{$\begin{array}{l}\text { Temporary } \\
\text { other arrangem. }\end{array}$} & -0.396 & -0.529 & -0.0768 & -0.160 & $-0.565 * *$ & $-0.942 * * *$ & $-0.568 * *$ & -0.410 & $-1.116^{* * *}$ & $-0.811 * * *$ \\
\hline & $(0.321)$ & $(0.340)$ & $(0.288)$ & $(0.344)$ & $(0.280)$ & $(0.301)$ & $(0.273)$ & $(0.302)$ & $(0.324)$ & $(0.291)$ \\
\hline \multirow[t]{2}{*}{ North-East } & $2.379 * * *$ & 0.0773 & $1.362 * * *$ & $1.271 * * *$ & $1.471 * * *$ & -0.635 & $0.657 * *$ & 0.508 & 0.419 & -0.291 \\
\hline & $(0.454)$ & $(0.937)$ & $(0.475)$ & $(0.251)$ & $(0.470)$ & $(0.609)$ & $(0.256)$ & $(0.350)$ & $(0.822)$ & $(0.238)$ \\
\hline \multirow[t]{2}{*}{ Centre } & $1.138^{*}$ & 0.543 & 0.443 & 0.197 & 0.559 & -1.095 & -0.110 & 0.908 & -0.270 & -0.566 \\
\hline & $(0.674)$ & $(0.698)$ & $(0.470)$ & $(0.471)$ & $(0.600)$ & $(1.244)$ & $(0.882)$ & $(0.708)$ & $(0.888)$ & $(0.533)$ \\
\hline \multirow[t]{2}{*}{ South-Islands } & 0.799 & -0.0451 & 0.134 & $0.795 * *$ & -0.315 & 0.106 & 0.228 & 0.562 & 0.127 & -0.497 \\
\hline & $(0.673)$ & $(0.542)$ & $(0.370)$ & $(0.353)$ & $(0.496)$ & $(0.528)$ & $(0.465)$ & $(0.527)$ & $(0.584)$ & $(0.409)$ \\
\hline \multirow{2}{*}{$\begin{array}{l}\text { Secondary } \\
\text { education }\end{array}$} & -0.0326 & 0.0402 & -0.207 & 0.0292 & -0.0365 & 0.0625 & -0.0663 & $0.405^{* *}$ & $0.442 *$ & $0.469 * *$ \\
\hline & $(0.188)$ & $(0.233)$ & $(0.206)$ & $(0.195)$ & $(0.221)$ & $(0.210)$ & $(0.221)$ & $(0.201)$ & $(0.239)$ & $(0.237)$ \\
\hline \multirow{2}{*}{$\begin{array}{l}\text { Tertiary } \\
\text { education }\end{array}$} & -0.0203 & -0.192 & $-0.467^{*}$ & -0.231 & -0.292 & -0.0135 & -0.251 & 0.241 & -0.0119 & 0.0647 \\
\hline & $(0.234)$ & $(0.274)$ & $(0.263)$ & $(0.256)$ & $(0.257)$ & $(0.270)$ & $(0.292)$ & $(0.250)$ & $(0.302)$ & $(0.281)$ \\
\hline \multirow[t]{2}{*}{ Medium skilled } & -0.0887 & -0.00850 & -0.0707 & $-0.236 * * *$ & $0.209 * * *$ & $-0.146 * *$ & 0.0466 & $-0.326 * * *$ & -0.0268 & $-0.107^{*}$ \\
\hline & $(0.0698)$ & $(0.0723)$ & $(0.0725)$ & $(0.0731)$ & $(0.0780)$ & $(0.0722)$ & $(0.0727)$ & $(0.0754)$ & $(0.0726)$ & $(0.0643)$ \\
\hline \multirow[t]{2}{*}{ Low skilled } & 0.0149 & 0.0298 & 0.0129 & -0.162 & 0.155 & -0.0833 & -0.126 & $-0.366^{*}$ & $-0.335^{*}$ & $-0.446 * *$ \\
\hline & $(0.189)$ & $(0.240)$ & $(0.162)$ & $(0.174)$ & $(0.177)$ & $(0.183)$ & $(0.201)$ & $(0.193)$ & $(0.181)$ & $(0.176)$ \\
\hline \multirow[t]{2}{*}{ Manufacturing } & -0.190 & -0.261 & 0.501 & $0.855 * * *$ & 0.197 & $0.606^{* *}$ & 0.118 & 0.462 & -0.298 & 0.0901 \\
\hline & $(0.219)$ & $(0.261)$ & $(0.324)$ & $(0.266)$ & $(0.296)$ & $(0.253)$ & $(0.259)$ & $(0.312)$ & $(0.308)$ & $(0.360)$ \\
\hline \multirow[t]{2}{*}{ Construction } & $0.468^{*}$ & 0.103 & $0.860^{*}$ & $1.351 * * *$ & $0.914 * * *$ & $1.529 * * *$ & $0.633^{*}$ & $0.930 * *$ & 0.207 & $0.716^{*}$ \\
\hline & $(0.239)$ & $(0.314)$ & $(0.458)$ & $(0.377)$ & $(0.337)$ & $(0.350)$ & $(0.330)$ & $(0.429)$ & $(0.357)$ & $(0.396)$ \\
\hline \multirow[t]{2}{*}{ Trade and food } & 0.00680 & -0.252 & $0.542 *$ & $0.841 * * *$ & -0.00729 & $0.693 * * *$ & 0.0754 & 0.312 & 0.0327 & 0.265 \\
\hline & $(0.186)$ & $(0.198)$ & $(0.321)$ & $(0.254)$ & $(0.284)$ & $(0.242)$ & $(0.243)$ & $(0.310)$ & $(0.293)$ & $(0.341)$ \\
\hline \multirow[t]{2}{*}{ Services } & 0.00707 & -0.122 & 0.453 & $0.914 * * *$ & 0.0749 & $0.760 * * *$ & 0.102 & 0.346 & -0.0196 & 0.252 \\
\hline & $(0.170)$ & $(0.177)$ & $(0.316)$ & $(0.248)$ & $(0.276)$ & $(0.237)$ & $(0.240)$ & $(0.313)$ & $(0.302)$ & $(0.336)$ \\
\hline \multirow[t]{2}{*}{ Constant } & 1.486 & 1.766 & 0.226 & -1.541 & -2.790 & 1.724 & 3.364 & 0.274 & 2.662 & 2.539 \\
\hline & (1.954) & $(1.995)$ & $(2.020)$ & (1.968) & $(2.084)$ & $(2.142)$ & $(2.134)$ & $(2.250)$ & $(1.845)$ & $(1.867)$ \\
\hline Observations & 1,721 & 1,728 & 1,722 & 1,730 & 1,705 & 1,691 & 1,713 & 1,710 & 1,709 & 1,735 \\
\hline R-squared & 0.098 & 0.090 & 0.109 & 0.148 & 0.125 & 0.122 & 0.135 & 0.117 & 0.181 & 0.179 \\
\hline
\end{tabular}

See the notes to Table 3 . Robust standard errors in parentheses; ${ }^{* * *} \mathrm{p}<0.01,{ }^{* *} \mathrm{p}<0.05,{ }^{*} \mathrm{p}<0.1$ 
Table 5: Gross income (logs) - OLS estimates

\begin{tabular}{|c|c|c|c|}
\hline VARIABLES & Total sample & Males & Females \\
\hline \multirow[t]{2}{*}{$25<\mathrm{BMI}<30$} & 0.0440 & 0.0433 & 0.0240 \\
\hline & $(0.0284)$ & $(0.0333)$ & $(0.0513)$ \\
\hline \multirow[t]{2}{*}{$\mathrm{BMI} \geq 30$} & 0.0149 & -0.0293 & 0.0633 \\
\hline & $(0.0661)$ & $(0.0577)$ & $(0.113)$ \\
\hline \multirow[t]{2}{*}{ Smoke } & 0.0212 & 0.00290 & 0.0314 \\
\hline & $(0.0263)$ & $(0.0372)$ & $(0.0416)$ \\
\hline \multirow[t]{2}{*}{ Age } & $-1.971 * *$ & $-8.095 * *$ & \\
\hline & $(0.968)$ & $(3.725)$ & \\
\hline \multirow[t]{2}{*}{ Age squared } & 0.0272 & $0.128 * *$ & $-0.0122 * * *$ \\
\hline & $(0.0181)$ & $(0.0600)$ & $(0.00236)$ \\
\hline \multirow[t]{2}{*}{ Kids } & -0.176 & 0.225 & $-2,862$ \\
\hline & $(0.266)$ & $(0.166)$ & $(4,350)$ \\
\hline \multirow[t]{2}{*}{ \# family comp. } & -0.0876 & -0.0674 & $-0.170^{*}$ \\
\hline & $(0.0712)$ & $(0.107)$ & $(0.0948)$ \\
\hline \multirow[t]{2}{*}{ \# family comp. sq. } & 0.0139 & 0.0151 & 0.0186 \\
\hline & $(0.0112)$ & $(0.0179)$ & $(0.0135)$ \\
\hline \multirow{2}{*}{$\begin{array}{l}\text { Temporary } \\
\text { employee }\end{array}$} & -0.0126 & -0.0389 & 0.00376 \\
\hline & $(0.0531)$ & $(0.0578)$ & $(0.0970)$ \\
\hline \multirow{2}{*}{$\begin{array}{l}\text { Temporary } \\
\text { other arrangem. }\end{array}$} & -0.0783 & -0.139 & -0.0845 \\
\hline & $(0.125)$ & $(0.171)$ & $(0.198)$ \\
\hline \multirow[t]{2}{*}{ North-East } & $-0.400 * *$ & -0.161 & $-0.530 * * *$ \\
\hline & $(0.168)$ & $(0.502)$ & $(0.137)$ \\
\hline \multirow[t]{2}{*}{ Centre } & -0.431 & 0.0864 & -0.530 \\
\hline & $(0.301)$ & $(0.343)$ & $(0.385)$ \\
\hline \multirow[t]{2}{*}{ South-Islands } & $-0.343 * *$ & $-0.386 * * *$ & -0.163 \\
\hline & $(0.154)$ & $(0.142)$ & $(0.265)$ \\
\hline \multirow{2}{*}{$\begin{array}{l}\text { Secondary } \\
\text { education }\end{array}$} & 0.00399 & -0.0830 & 0.161 \\
\hline & $(0.0672)$ & $(0.0813)$ & $(0.116)$ \\
\hline \multirow{2}{*}{$\begin{array}{l}\text { Tertiary } \\
\text { education }\end{array}$} & -0.0727 & -0.170 & 0.106 \\
\hline & $(0.103)$ & $(0.133)$ & $(0.163)$ \\
\hline \multirow[t]{2}{*}{ Medium skilled } & -0.0104 & 0.0355 & $-0.0742 *$ \\
\hline & $(0.0287)$ & $(0.0463)$ & $(0.0394)$ \\
\hline \multirow[t]{2}{*}{ Low skilled } & 0.00623 & 0.0685 & $-0.174 *$ \\
\hline & $(0.0413)$ & $(0.0492)$ & $(0.0982)$ \\
\hline \multirow[t]{2}{*}{ Manufacturing } & 0.0203 & -0.0147 & 0.0862 \\
\hline & $(0.0573)$ & $(0.0621)$ & $(0.121)$ \\
\hline \multirow[t]{2}{*}{ Construction } & -0.00631 & -0.0415 & -0.0467 \\
\hline & $(0.0744)$ & $(0.0804)$ & $(0.157)$ \\
\hline \multirow[t]{2}{*}{ Trade and food } & $-0.106^{*}$ & $-0.141 * *$ & -0.0958 \\
\hline & $(0.0582)$ & $(0.0673)$ & $(0.115)$ \\
\hline \multirow[t]{2}{*}{ Services } & -0.0532 & -0.0306 & -0.111 \\
\hline & $(0.0560)$ & $(0.0597)$ & $(0.112)$ \\
\hline \multirow[t]{2}{*}{ Male } & $0.227 * * *$ & & \\
\hline & $(0.0380)$ & & \\
\hline \multirow[t]{2}{*}{ Constant } & $11.75 * * *$ & $23.74 * * *$ & $8.503 * * *$ \\
\hline & $(2.109)$ & $(7.264)$ & $(0.954)$ \\
\hline Observations & 2,919 & 1,175 & 1,744 \\
\hline R-squared & 0.207 & 0.240 & 0.157 \\
\hline
\end{tabular}

See the notes to Tables 2 and 3 .

Robust standard errors in parentheses; ${ }^{* * *} \mathrm{p}<0.01,{ }^{* *} \mathrm{p}<0.05,{ }^{*} \mathrm{p}<0.1$ 